\title{
THE COMMONWEALTH PRINCIPLES (LATIMER HOUSE) ON THE RELATIONSHIP BETWEEN THE THREE BRANCHES OF GOVERNMENT: TWENTY YEARS ON
}

\author{
Karen Brewer and Peter Slinn*
}

\begin{abstract}
2018 marks the twentieth anniversary of the Latimer House 'process' which commenced with the drafting of the Latimer House Guidelines for the Commonwealth on Good Practice Governing Relations between the Executive, Parliament and the Judiciary. Since then the Latimer House Guidelines have been transformed into the Commonwealth Principles (Latimer House) on the Relationship between the Three Branches of Government which have been endorsed by Commonwealth Heads of Government on several occasions.

This article assesses the role of the Latimer House process over the last two decades against the background of the Commonwealth's evolving commitments to good governance and the rule of law. Part 1 explores the role of the Commonwealth in supporting good governance and the rule of law whilst Part 2 considers and evaluates the Latimer House process itself. Part 3 reviews the development of the Commonwealth Principles in practice whilst in Part 4 some specific implementation issues concerning the judiciary are discussed. Part 5 considers the future development of the Commonwealth Principles whilst Part 6 provides a conclusion and overview.
\end{abstract}

Keywords: Latimer House 'process'; Latimer House Guidelines; relations between Executive, Parliamentary and judiciary; Commonwealth Principles (Latimer House); good governance; rule of law; The Commonwealth (of nations); Commonwealth law ministers; Commonwealth heads of government; intergovernmental policy; Latimer House Toolkit; Commonwealth Ministerial

* Dr Karen Brewer is Secretary General of the Commonwealth Magistrates' and Judges' Association. Dr Peter Slinn is Vice-President of the Commonwealth Legal Education Association. The associations were co-sponsors (with the Commonwealth Lawyers Association and the Commonwealth Parliamentary Association) of the Joint Colloquium which adopted the Latimer House Guidelines in 1998. As members of the Latimer House Working Group, both Dr Brewer and Dr Slinn have remained closely involved with the promotion and implementation of the Latimer House Principles. 
Action Group; Edinburgh Plan of Action; Harare Principles; democratically elected governments - overthrow of; Declaration of Commonwealth Principles; appointment-discipline-removal of judges gender balance in parliament; expulsion of members of Parliament; CHOGM (Commonwealth Heads of Government Meeting); Commonwealth Ministerial Action Group; Commonwealth associations; The Modern Commonwealth.

\section{INTRODUCTION}

2018 marks the twentieth anniversary of the Latimer House 'process' which commenced with the drafting of the Latimer House Guidelines for the Commonwealth on Good Practice Governing Relations between the Executive, Parliament and the Judiciary. Since then the Latimer House Guidelines have been transformed into the Commonwealth Principles (Latimer House) on the Relationship between the Three Branches of Government which, as noted below, have been endorsed by Commonwealth Heads of Government on several occasions.

This article assesses the role of the Latimer House process over the last two decades against the background of the Commonwealth's evolving commitments to good governance and the rule of law. Part 1 explores the role of the Commonwealth in supporting good governance and the rule of law whilst Part 2 considers and evaluates the Latimer House process itself. Part 3 reviews the development of the Commonwealth Principles in practice whilst in Part 4 some specific implementation issues concerning the judiciary are discussed. Part 5 considers the future development of the Commonwealth Principles whilst Part 6 provides a conclusion and overview.

\section{PART 1. THE COMMONWEALTH, GOOD GOVERNANCE AND THE RULE OF LAW}

The Commonwealth is a voluntary association of fifty-three independent and equal sovereign states that uniquely is not formed by a binding treaty such as that established through membership of the United Nations. Consensus has been at the heart of the Commonwealth association ever since, but the nature of that consensus has evolved since 1950 in both scope and complexity.

In 1949, the governments of the then eight members of what was still styled at the beginning as the 'British Commonwealth of Nations' adopted the Declaration of London, identified by Sir William Dale as the 'foundation document of the modern Commonwealth'. The Declaration was primarily concerned with the

1 The text is found in Sir William Dale, The Modern Commonwealth (Butterworths 1983) 39. 
ingenious formula whereby India could remain a member of the (no longer British) Commonwealth after becoming a republic on the basis of the acceptance of the British King as 'a symbol of the free association of its independent member nations and as such Head of the Commonwealth'. The principles guiding this re-branded association were alluded to in the vaguest terms: members declared that they remained 'united as free and equal members of the Commonwealth of Nations, freely co-operating in the pursuit of peace, liberty and progress' [our italics].

From 1949 until 1969, regular meetings of Commonwealth 'Prime Ministers' (28 heads of government by 1969) issued increasingly lengthy communiqués dealing with matters of common concern such as the Rhodesia (now Zimbabwe) crisis, the Middle East, trade, aid and development. The communiqués contained no general statement of principles, though it could be discerned that the Commonwealth consensus embraced notions of democratic governance, international co-operation, peaceful settlement of disputes and the promotion of economic development. More particularly, the 1964 communiqué referred to race relations and the need for each member country to build a structure of society 'which offers equal opportunity and non-discrimination for all its people, irrespective of race, colour or creed'. ${ }^{2}$

In 1971, at their meeting in Singapore, Commonwealth Heads of Governments (the designation replacing that of Commonwealth Prime Ministers, given that a number of members now had executive presidents) took the significant step of adopting a Declaration of Commonwealth Principles. This included a clear commitment to democratic political processes:

We believe in the liberty of the individual, in equal rights for all citizens regardless of race, colour, creed or political belief, and in their inalienable right to participate by means of free and democratic political processes in framing the society in which they live. We therefore strive to promote in each of our countries those representative institutions and guarantees for personal freedom under the law that are our common heritage. ${ }^{3}$

Two subsequent declarations in 1977 and 1979 were concerned with addressing apartheid in sport and the elimination of racism and racial prejudice. However in 1991, Heads of Government adopted the Harare Commonwealth Declaration as a more detailed statement of the fundamental Principles set out at Singapore, with a

2 Meeting of Commonwealth Prime Ministers, 1964, Final Communiqué, The Commonwealth at the Summit, Commonwealth Secretariat, (1987) 83.

${ }^{3}$ Ibid 156-57. 


\section{THE COMMONWEALTH PRINCIPLES (LATIMER HOUSE) ON THE RELATIONSHIP BETWEEN THE THREE BRANCHES OF GOVERNMENT}

commitment to the protection and promotion of the fundamental political values of the Commonwealth, i.e:

- Democracy, democratic processes and institutions which reflect national circumstances, the rule of law and the independence of the judiciary, just and honest government;

- Fundamental human rights, including equal rights and opportunities for all citizens regardless of race, colour, creed or political belief. ${ }^{4}$

Heads of Government also pledged themselves to work, inter alia, for equality for women, 'so that they may exercise their full and equal rights'.

These references to the rule of law, democratic processes, fundamental human rights and equality for women provided the inspiration for the future Latimer House process. The Harare Declaration contained no provisions for enforcement or compliance monitoring. However, at their Meeting in Auckland in 1995, Heads of Government adopted The Millbrook Action Programme on the Harare Declaration. ${ }^{5}$ This established the Commonwealth Ministerial Action Group (CMAG) on the Harare Declaration 'in order to deal with serious and persistent violations' of the principles contained in that Declaration, in particular in the event of the overthrow of a democratically elected government. CMAG's task was to recommend measures to restore democracy and constitutional rule, including as a last resort suspension from membership of the association. It may be thought that because of its nature as a voluntary association of nations, the Commonwealth might not have effective power to persuade individual countries to conform to its principles. Certainly some 'suspended' countries have flirted or threatened to join other international entities, for example Nigeria joined the Francophonie after it was suspended from the Commonwealth in 1995. However, with the exception of Zimbabwe and the Maldives which, when threatened with the process, chose to leave the Commonwealth, the historic ties of member nations has provided a driving force behind compliance with the requests from the Commonwealth in regard to the re-establishment of democratic processes in The Gambia, Nigeria, Pakistan, Fiji Islands and the Solomon Islands. ${ }^{6}$

4 Commonwealth Statement on Apartheid in Sport (the Gleneagles Agreement) (1977); Meeting of Commonwealth Prime Ministers (n 3) 198; Lusaka Declaration of the Commonwealth on Racism and Racial Prejudice (1979); Meeting of Commonwealth Prime Ministers (n 3) 217; Harare Commonwealth Declaration vol 2, p 82.

5 Harare Commonwealth Declaration vol 2, p 156.

6 In 2018, Zimbabwe applied to re-join the Commonwealth. 


\section{THE LATIMER HOUSE PROCESS}

The Harare Declaration invited the Commonwealth Parliamentary Association and non-governmental Commonwealth organisations to play their full part in the promotion of the objectives of the Declaration. At a meeting of Commonwealth Law Ministers in 1996, the importance of the role played by judges and lawyers in a 'healthy democracy' was recognised. ${ }^{7}$ It was against this background that four Commonwealth associations, namely the Commonwealth Parliamentary Association (CPA), Commonwealth Magistrates' and Judges' Association (CMJA), Commonwealth Lawyers Association (CLA) and Commonwealth Legal Education Association (CLEA) came together in a Joint Colloquium in 1998 at Latimer House, a country house conference centre in Buckinghamshire in the United Kingdom. They were supported in their endeavours by the Commonwealth Secretariat, the Commonwealth Foundation and the British Foreign and Commonwealth Office.

The Colloquium brought together for the first time a senior-level group of over fifty participants from twenty-three jurisdictions, including parliamentarians, some holding ministerial office, judges, legal practitioners and legal academicians, to adopt a Commonwealth Model on 'Parliamentary Supremacy and Judicial Independence'. The object was not only the promotion of dialogue between those at the cutting edge of good governance issues. The Colloquium had the specific aim of drafting detailed guidelines as to best practice with regard to relations between the executive, parliament and the judiciary in the promotion of good governance, the rule of law and human rights to ensure the effective implementation of the Harare Principles. The Latimer House Guidelines on Parliamentary Supremacy and Judicial Independence (the Guidelines) which emerged from the deliberations and were adopted by consensus, were intended as an operational manual of good practice rather than yet another highsounding declaration of principle (of which the Commonwealth was proving itself only too adept). As recalled at the beginning of this article, it is now twenty years since the drafting of the Guidelines, an initiative, it should be stressed, of the four partner organisations, not of Commonwealth governments.

The Preamble to the Guidelines recited the fundamental political values of the Commonwealth quoted above from the Harare Declaration. ${ }^{8}$ From these values

7 Communiqué of the Meeting of Commonwealth Law Ministers 1996.

8 The full text of the Guidelines and subsequent documentation, including the Principles (see below) are conveniently set out in a booklet published by the four sponsoring organisations <https://www.cmja.org/downloads/latimerhouse/commprinthreearms.pdf> accessed 20 November 2018. A full account of the Latimer House deliberations can be found in John Hatchard and Peter Slinn (eds) Parliamentary Supremacy and Judicial Independence: A Commonwealth Approach (Cavendish Publishing Ltd 1999). 


\section{THE COMMONWEALTH PRINCIPLES (LATIMER HOUSE) ON THE RELATIONSHIP BETWEEN THE THREE BRANCHES OF GOVERNMENT}

the Guidelines adopted the principle that, in terms of the relationship between executive, parliament and the judiciary, each 'institution must exercise responsibility and restraint in the exercise of power within its own constitutional sphere so as not to encroach on the legitimate discharge of constitutional functions by the other institutions'. In essence, the doctrine of separation of powers was imported into the fundamental values of the Commonwealth.

The document then set out in some detail guidelines concerning the relationship between Parliament and the judiciary, the independence of judges and parliamentarians, the role of women in parliament, judicial and parliamentary ethics, accountability mechanisms, the law-making process, the role of non-judicial and non-parliamentary institutions, and measures for implementation and monitoring compliance with the Guidelines. The Guidelines also dealt with a number of controversial issues, such as the expulsion of members of Parliament for 'floor-crossing', gender balance in parliament and the appointment, discipline and removal of judges.

The Guidelines attracted wide notice throughout the Commonwealth and their adoption was the beginning of a 'Latimer House process' which continues to this day. This process was fostered by the determined advocacy of the four sponsoring organisations through what were styled the 'red channel' (via Commonwealth governments and governmental institutions) and the 'green channel' (via independent non-governmental organisations and activities). These channels were interrelated in the sense that the partner organisations recognised that, if the Guidelines were to be implemented effectively, they would require endorsement by Commonwealth governments. On the other hand the partner organisations needed to retain freedom to hold governmental agencies to account for perceived breaches of the Guidelines. The Commonwealth legal community were made aware of the Guidelines through publicity at conferences of lawyers, legal educators and parliamentarians sponsored by the partner organisations, so that, for example, references to the Guidelines began to appear in judicial pronouncements. ${ }^{9}$

9 In September 1999, the Chief Justice of Trinidad and Tobago referred to the Guidelines in his Opening of the Legal Year Speech in publicly expressing concern over a perceived threat to the independence of the judiciary in his jurisdiction: see <http://webopac.ttlawcourts.org/ LawTermOpen/1999.pdf $>$ accessed 20 November 2018. In the same year, the Guidelines were cited for the first time in a Commonwealth Court. The High Court of Judiciary in Scotland referred to the Guidelines in holding that a temporary sheriff appointed on an annual renewal basis by the executive did not constitute an independent and impartial tribunal as required by the fair trial provisions of the European Convention on Human Rights: Starrs v Procurator Fiscal (Linlithgow) [2000] 1 LRC 718, 737 and 765. Subsequent citations of the Guidelines/Principles from around the Commonwealth include that of the Chief Justice of Tonga in Tu'ifua v Public Service Tribunal [2014] 5 LRC 588, [15]. 
Remarkable progress was made through the 'red channel'. Beginning in 1999, representatives of the partner organisations were invited to participate in a lengthy process of consultation at Commonwealth official and ministerial level leading to the formation of a Joint Working Party of Ministers and representatives of the four partner organisations. This resulted in a 'refinement' of the Guidelines into the Commonwealth (Latimer House) Principles on the Accountability of and Relationship between the Three Branches of Government (The Commonwealth Principles). Commonwealth Heads of Government at their meeting at Abuja, Nigeria, in December 2003:

...[E]ndorsed the recommendation of their Law Ministers on Commonwealth Principles on the accountability of and relationship between the three branches of government. They acknowledged that judicial independence and delivery of efficient justice services were important for maintaining the balance of power between the Executive, Legislature and Judiciary. ${ }^{10}$

At their next meeting in Malta in 2005, Heads of Government:

...[N]oted that the Commonwealth (Latimer House) Principles ... 2003, which recognised the importance of a balance of power between the Executive, Legislature and Judiciary, constitute an integral part of the Commonwealth's fundamental political values as set out in the Harare Declaration'(emphasis added). ${ }^{11}$

This was affirmed at the Commonwealth Heads of Government meeting in London in 2018.

\section{THE COMMONWEALTH PRINCIPLES: STATUS AND ENFORCEMENT}

What had begun as a set of Guidelines drafted at an unofficial gathering of lawyers, legal academics, politicians and judicial officers from around the Commonwealth had now emerged, through a process of consultation in which the unofficial partners had played a full part, as a set of Principles accepted by all Commonwealth member states as 'an integral part' of their fundamental political values. As Richard Bourne, a leading commentator on Commonwealth affairs, has observed:

10 Abuja Communiqué, para 8, The Commonwealth at the Summit, vol 3 (Commonwealth Secretariat 1997) 131.

${ }^{11}$ Malta Communiqué, para 8; Abuja Communiqué (n 10) 172. 
At the Abuja CHOGM, leaders not only approved [the Commonwealth Principles] but, in an unprecedented move, attached them to the 1991 Commonwealth Harare Declaration. This was a spectacular example of the impact of the Commonwealth associations on intergovernmental policy, even though practice in countries as varied as Pakistan and Uganda has failed to live up to it. ${ }^{12}$

Bourne has identified several crucial elements of the Latimer House process which should be of general interest to all lawyers concerned with public law in both domestic and international spheres, namely the role of Commonwealth associations in shaping the development of the fundamental values of the Commonwealth, the legal status of such Principles and the problem of compliance.

\section{i) The role of the Commonwealth associations in shaping the intergovernmental organisation's fundamental values}

An examination of the Latimer House process suggests that the Commonwealth has evolved a system whereby organisations independent of government can play a full part in the development of principles which governments may endorse. Of course there is nothing new about recognising the influence of civil society on international policy-making as is witnessed in the environmental sphere. However, the devising of the Commonwealth Principles represents a significant example of cooperation between ministers, their officials and the Commonwealth Secretariat on the one hand, and the partner organisations on the other, thus overcoming the suspicion with which ministers and officials often regard 'civil society' groups which may be perceived as attempting to insert themselves into decision-making processes which are the sole prerogative of elected governments.

\section{ii) The legal status of the Commonwealth Principles}

The reference in the Malta Communiqué is to the Principles as being part of the fundamental political values of the Commonwealth. Does this mean that the Harare Declaration and other instruments emerging from the CHOGMs are merely statements of political intent and of no legal or normative effect?

The legal significance of Commonwealth Declarations was analysed some thirty-five years ago by Sir William Dale in his seminal work The Modern

12 Richard Bourne, 'The Commonwealth and Civil Society' in James Mayal (ed.) The Contemporary Commonwealth: An Assessment 1965-2009 (Routledge 2010) 128. 
Commonwealth. ${ }^{13}$ As noted earlier, Commonwealth member states are not mutually bound by agreements binding in international law so as to attract registration under Article 102 of the United Nations Charter. However, Dale concluded:

The Commonwealth Declarations emanate, as do the United Nations Declarations, from an organised body, the Heads of Government Meeting, a principal organ of the Commonwealth Association... The Heads of Government are able to ensure -subject to the requirements of their domestic Constitutions - that [the commitments contained in the Declarations] are carried out.... The instruments may also, as evidence of state practice, contribute to customary international law. ${ }^{14}$

The issue has been further explored, in the light of developments since 1983, by one of the present writers who argues that, at the very least, Commonwealth Declarations fit comfortably into the character of 'soft law'. Non-binding legal instruments may involve commitments in good faith which are expected to have normative significance for the way states behave $1{ }^{15}$ Commonwealth Declarations in relation to human rights, the rule of law, gender equality and good governance, as particularly reflected in the Commonwealth (Latimer House) Principles, thus reinforce the development of international law and processes whereby:

Both textually and in practice the international legal system is moving towards a clearly defined democratic entitlement, with national governance validated by international standards and instruments and systematic monitoring of compliance. ${ }^{16}$

This approach is strengthened by the inclusion of the Commonwealth (Latimer House) Principles as an integral part of the 'Affirmation of Commonwealth Values and Principles' by Heads of Government meeting in Trinidad and Tobago in 2009. As we shall see, the Principles are also embodied in the Commonwealth Charter of 2013. ${ }^{17}$

13 Dale (n 1) 48-51. Dale had been legal adviser in the Commonwealth Office when it was a separate department of state in the United Kingdom government.

14 Ibid.

15 Peter Slinn, 'The Commonwealth and the Law' in Mayal, op cit, pp 32-34.

16 Thomas Franck, Fairness in International Law and Institutions (OUP 1995) 139, quoted in Slinn (n 15).

17 Available at <http://thecommonwealth.org/our-charter> accessed 20 November 2018. 
iii) Monitoring of compliance

The 'systematic monitoring of compliance' has proved problematic as far as the Commonwealth (Latimer House) Principles are concerned. The original 1998 Guidelines envisaged that:

[I]f these Guidelines are adopted, an effective monitoring procedure, which might include a Standing Committee, should be devised under which all Commonwealth jurisdictions accept an obligation to report on their compliance with these Guidelines.... Considerations of these reports should form a regular part of the meetings of Law Ministers and Heads of Government. ${ }^{18}$

Whilst the CMJA, CLA and CLEA have tried to establish their own monitoring mechanism and other Commonwealth-accredited organisations have called for some form of evaluation of the implementation of Commonwealth fundamental values, ${ }^{19}$ funding has proved elusive to date for such a venture. The Principles, as they emerged at Abuja, from the process of refinement, contain no reference to such procedures, merely stating that the objective is:

...[T]o provide, in accordance with the laws and customs of each Commonwealth country, an effective framework for the implementation by governments, parliaments and judiciaries of the Commonwealth's fundamental values. $^{20}$

In 2005, a forum of representatives from all eighteen African Commonwealth countries organised by the Commonwealth Secretariat led to the production of a Plan of Action for Africa (The Nairobi Plan of Action for Africa) on the implementation of the Principles. This was adopted in revised form for the Commonwealth as a whole at a colloquium held in Edinburgh in 2008. These plans of action urged governments to establish mechanisms to monitor and evaluate their implementation in their respective jurisdictions. Whilst the Nairobi Plan of Action for Africa was endorsed by governments, this was not the case with the Edinburgh

18 Guideline IX 'Measures for Implementation and Monitoring Compliance', Secretariat text, p 23 <www.cmja.org > accessed 20 November 2018.

19 'Democracy in the Commonwealth: A report on Democracy 18 years after the Harare Declaration' produced for Electoral Reform International (ERIS) and the Commonwealth Policy Studies Unit (CPSU) 2009 by Kwadwo Afari Gyan, Asma Jahangir and Tim Sheehy.

20 See booklet (n 8) 10. 
Plan of Action and no mechanism for evaluating the implementation was established. $^{21}$

However, the question of the implementation of the Principles has remained on the agenda of Commonwealth Law Ministers. In 2011, Commonwealth Law Ministers adopted recommendations from a Rule of Law Expert Group to encourage Heads of Government to give better effect to them. ${ }^{22}$ In yet another report commissioned by Heads of Government, an Eminent Persons Group (EPG) considered means of strengthening the core values of the Commonwealth. The EPG recommended the appointment of a Commonwealth Commissioner for Democracy, Rule of Law and Human Rights and the adoption of a Charter for the Commonwealth encapsulating in a single document the principles embodied in the Singapore and subsequent declarations and statements. The Commissioner proposal foundered on the unwillingness of governments and of the then Secretary General to accept an independent monitoring mechanism of any kind.

However, the Charter proposal did find favour. After much amendment of the original draft appended to the EPG report by Michael Kirby, a distinguished former Australian High Court judge, the Charter was adopted in 2012 and formally signed in March by the Head of the Commonwealth. ${ }^{23}$ However, this Charter is not a legal instrument binding on member states. It is a declaration by 'We the people of the Commonwealth' of the core values and principles of the organisation, including those of Latimer House. Perhaps not surprisingly, there are no references to any monitoring or enforcement mechanisms and the Charter appears to be aspirational in nature rather than prescriptive.

It might appear that a decisive step had been taken to ensure the implementation of the Commonwealth's fundamental values at the Auckland CHOGM in 1995 by the establishment of the Commonwealth Ministerial Action Group (CMAG) which comprised a rotating group of nine ministers of foreign affairs, i.e. a governmental peer review mechanism. As noted above, CMAG has proved of limited effectiveness except where a complete breakdown of constitutional governance has occurred. However, in $2011 \mathrm{CMAG}$, as a watchdog protecting the Commonwealth fundamental values, moved from considering only military or coup-led attacks against democracy, to dealing with 'serious or persistent violations of Commonwealth fundamental political values that do not involve an unconstitutional overthrow of a democratically

\footnotetext{
21 Ibid 47.

22 Communiqué of the Commonwealth Law Ministers Meeting, Sydney, Australia 2011.

23 The text of the Charter was presented to the British parliament as a command paper in March, 2013, Cm 8572. Commonwealth Accredited Organisations were given the opportunity to make submissions and the Latimer House Working Group made a submission which was to some extent reflected in the text.
} 
elected government'. CMAG recognised that the Commonwealth had 'added important principles to those contained in the Harare Declaration such as the Commonwealth (Latimer House) Principles', so that CMAG now had a mandate to invoke breaches of the Principles in calling a government to account for serious or persistent violations of Commonwealth fundamental values. ${ }^{24}$

The difficulties posed by a CMAG intervention on this basis may be illustrated by the example of the Maldives. In September 2016, the Maldives government was given six months by CMAG to address concerns including the detention and prosecution of opposition leaders, interference with the judiciary and undermining of democratic institutions. The response of the Maldives Government was to leave the Commonwealth, alleging that it had been treated unjustly and unfairly by CMAG, and that the Maldives were being targeted by CMAG and the Commonwealth Secretariat 'in the name of democratic promotion, to increase the Commonwealth's own relevance and leverage in international politics'. All the Commonwealth Secretary General could do was to express her 'sadness and disappointment'. ${ }^{25}$

\section{SPECIFIC PROBLEMS OF IMPLEMENTATION: THE CASE OF THE JUDICIARY}

Aside from cases referred to CMAG, there has been persistent evidence of breaches of the Commonwealth's fundamental values in jurisdictions which have never experienced military rule and which ostensibly maintained a democratic system under the rule of law. As discussed below, it has been left to the Latimer House Group, working outside of government through the 'green channel', to draw attention to these breaches and attempt to hold governments to account. Upholding the independence of the judiciary provides an important case study.

In a number of instances the independence and personal safety of judicial officers and parliamentarians has been threatened. For example, a military takeover in Pakistan led to the judges being required to take a new oath of office or face dismissal. Subsequently, the Supreme Court of Pakistan, in dealing with a constitutional challenge to the military take-over, vigorously asserted the independence of the judiciary. However, it found that the conduct of the deposed

24 Strengthening the Role of the Commonwealth Ministerial Action Group (CMAG) Report by CMAG adopted by the Commonwealth Heads of Government Meeting 2011 (Commonwealth Secretariat).

25 A succinct account of the withdrawal and reaction thereto can be found in Michael Safi, 'Maldives Quits Commonwealth over Alleged Rights Abuses' (The Guardian online 13 October 2016). 
democratically elected government had been such in terms of corruption, mismanagement and abuse of the independence of the judiciary and the rule of law as to justify the military intervention under the doctrine of necessity. However, after the restoration of civilian rule and of the dismissed judges, the Supreme Court nullified the earlier judgment and ruled the military take-over unlawful. ${ }^{26}$ In 2018, the political situation in Pakistan remains volatile. However, the election of the leader of the opposition as Prime Minister through a largely peaceful transition may mark a departure from the habitual chaos and violence of Pakistani politics. ${ }^{27}$

In some countries, such as Australia, the separation of the judiciary from legislative and executive powers and the separation of the judicial officers from political activity have been rigorously maintained. In other countries where the system is based on the Westminster model, checks and balances against abuse of power may not be as effective as in those countries which have enshrined the principle of constitutional supremacy so all actions of the organs of the state have to conform to the Constitution as the supreme law. An independent, honest and impartial judiciary is integral to upholding the rule of law, engendering public confidence and dispensing justice. In a number of Commonwealth countries despite the well-intentioned provisions in the Constitutions which provide for equality of opportunity, appointment on merit and the removal of gender and other historical discriminations, appointments are subject to the whims of the Executive.

The Principles outline the requirements of all Commonwealth countries to have in place a system where:

a. Judicial appointments should be made on the basis of clearly defined criteria and by a publicly declared process. The process should ensure:

- equality of opportunity for all who are eligible for judicial office;

- appointment on merit; and

- that appropriate consideration is given to the need for the progressive attainment of gender equity and the removal of other historic factors of discrimination;

b. Arrangements for appropriate security of tenure and protection of levels of remuneration must be in place;

c. Adequate resources should be provided for the judicial system to operate

26 Khan v Musharaf [2008] 4 LRC 157; Sindh High Court Bar Association v Pakistan [2010] 2 LRC 319.

27 Imran Khan, the former international cricketer was elected in August 2018. See also Interim Report of the Commonwealth Observer Group on the Pakistan Election July 2018 (available on the Commonwealth Secretariat Website). 


\section{THE COMMONWEALTH PRINCIPLES (LATIMER HOUSE) ON THE RELATIONSHIP BETWEEN THE THREE BRANCHES OF GOVERNMENT}

effectively without any undue constraints which may hamper the independence sought;

d. Interaction, if any, between the executive and the judiciary should not compromise judicial independence.

Well-established parliamentary procedures for the removal of judges exist in all Commonwealth Constitutions. However, these mainly affect judicial officers in the higher courts although even then some countries have disregarded the constitutional or parliamentary process. Magistrates and District Court judges may not benefit from the same security of tenure and can often be removed by a simple decision made by the Attorney General as happened in The Gambia under the Jammeh regime. This issue was highlighted at the 2018 Triennial Conference of the CMJA which adopted the Brisbane Declaration on the Independence and Integrity of Judicial Officers of the Lower Courts. ${ }^{28}$

Even the perception that there may not be security of tenure may require a change in the system of appointment. This was demonstrated in Scotland following the judgment in the Starrs $v$ Procurator Fiscal (Linlithgow) ${ }^{29}$ where it was successfully contended (citing what were then the Latimer House Guidelines) that the existing system of appointment of temporary Sheriffs brought into question their independence. As a result of this judgment, the system of appointing Sheriffs was radically changed and there are no longer any temporary Sheriffs in Scotland. In other cases where judicial officers do not benefit from constitutional protection, the same individual rights under article 10 of the Universal Declaration of Human Rights should apply to them. ${ }^{30}$

It is recognised that parliaments are primarily responsible for law-making. In some Commonwealth countries the judiciary has been charged with "judicial activism' especially in the area of human rights where since $1988^{31}$ judicial officers have increasingly made reference to norms established by international

\footnotetext{
28 Available on the CMJA website (n 18).
}

29 Linlithgow (n 9).

30 Article 10 provides that 'Everyone is entitled in full equality to a fair and public hearing by an independent and impartial tribunal, in the determination of [their] rights and obligations and of any criminal charge against [them]'.

31 The Judicial Colloquium on the Domestic Application of International Norms held in Bangalore, India, concluded inter alia that: 'It is within the proper nature of the judicial process and well-established judicial functions for national courts to have regard to international obligations which a country undertakes - whether or not they have been incorporated into domestic law - for the purpose of removing ambiguity or uncertainty from national Constitutions, legislation or common law'. 
treaties for the purpose of deciding cases where domestic common law is ambiguous. This is inevitable in a world which has been progressively moving towards globalisation. However, judicial officers remain sensitive to the fact that it is parliament that has primacy in the law-making process and that they are accountable to the Constitution and to the law. In most cases where this has happened, the country may have already signed and/or ratified an international convention but not integrated the international norms into domestic law. Article II of the Commonwealth Principles states:

a. Relations between parliament and the judiciary should be governed by respect for parliament's primary responsibility for law making on the one hand and for the judiciary's responsibility for the interpretation and application of the law on the other hand.

b. Judiciaries and parliaments should fulfil their respective but critical roles in the promotion of the rule of law in a complementary and constructive manner.

As the third pillar of democracy, the judiciary cannot operate without resources. In a number of instances, funding has been cut to the judiciary (whether through limitation of salaries, non-repair of court buildings or reduction of budgets for improving access to justice and similar projects) in order to exert influence over judicial officers who may not be toeing the executive line. Sufficient and sustainable funding needs to be provided to the judiciary so that it can perform its functions. It is recognised that shortfalls in national incomes have to be taken into account in all budgets. However, parliaments which are responsible for agreeing national budgets must ensure provision of adequate resources to the judiciary so that they can 'operate effectively without any undue constraints which may hamper the independence sought'. ${ }^{32}$

\section{TOWARDS IMPLEMENTING THE COMMONWEALTH PRINCIPLES}

A number of Commonwealth countries are already making progress in implementing the Commonwealth Principles. In the United Kingdom where the separation of the judiciary from the legislative and executive has been in modern times a strong convention of the Constitution, the major constitutional reforms enacted in 2005 removed perceived anomalies which appeared at variance with the principles embodied in the Latimer House Guidelines. For example, the Lord

${ }^{32}$ Article IV(c) of the Principles. 


\section{THE COMMONWEALTH PRINCIPLES (LATIMER HOUSE) ON THE RELATIONSHIP BETWEEN THE THREE BRANCHES OF GOVERNMENT}

Chancellor is now merely a government minister (and not necessarily a lawyer!), having lost both legislative and judicial roles. The Judicial Committee of the House of Lords was replaced with a Supreme Court, separated institutionally and physically from Parliament. Further, the informal system of judicial appointments has been replaced by a process involving a Judicial Appointments Commission. ${ }^{33}$ The United Kingdom can now be considered formally in compliance with the Commonwealth Principles. As an example of good practice, the Australian Capital Territory legislature commissioned an audit of the implementation of the Principles in the territory. ${ }^{34}$ Sadly, this audit precedent has not been followed in other jurisdictions.

The Commonwealth Principles are now firmly entrenched in the fundamental political values of the Commonwealth. However, given the refusal of Commonwealth governments to accept any formal monitoring mechanism (such as the Rule of Law Commissioner proposed by the EPG high-level review and the failure of CMAG to carry out its full mandate), the four sponsoring organisation have been left with the task of holding member states to account for any alleged breaches of the Principles. They have contributed to the development of tools to ensure best practice such as the Benchbooks for Legislatures produced by the Commonwealth Parliamentary Association ${ }^{35}$ and the Guide for the Magistrate in the Commonwealth: Fundamental Principles and Recommended Practices which was produced by the CMJA in 2017. They have also undertaken training for parliamentarians, lawyers and judicial officers and provided regular confidential briefings to meetings of Commonwealth law ministers and senior officials. In addition, the CLA, CLEA and CMJA have produced joint statements drawing public and official attention to such breaches. Joint statements in the form of press releases have been issued, inter alia, in relation to the impeachment of the Chief Justice of Sri Lanka, the forced removal and deportation of a Magistrate from Nauru, the removal of three judges in Zambia, the threat of impeachment of judges in Botswana, the arrest and detention of lawyers and judges in the Cameroon, executive threats against the judiciary in Kenya and threats to the position of the Chief Justices of Lesotho and the Seychelles. ${ }^{36}$ The effect of these statements is hard to assess. The intervention may have contributed to the restoration of the

33 For a succinct summary of the 2005 reforms, see David McClean, 'Judicial Reform in the United Kingdom' (2005) 16(1) Commonwealth Judicial Journal 25.

34 Report of the ACT Legislature 2009: available at <https://www.parliament.act.gov. au/_data/assets/pdf_file/0003/690213/2015-02-ACT-Report-on-the-Latimer-Principles. pdf $>$ accessed 20 November 2018.

35 See the website of the CPA at <www.cpa.org > accessed 20 November 2018.

36 The full texts of all these statements are available on the CMJA website: see $n 18$. 
impeached Chief Justice of Sri Lanka after a change of government in 2015 even though she promptly resigned her position. Also regarding the Seychelles, a report of a fact-finding mission by the Southern African Chief Justices Forum relies on the Principles and the Guidelines in relation to judicial accountability and judicial security of tenure. ${ }^{37}$

\section{The Commonwealth Principles and the role of an independent media}

The Principles closely follow the Guidelines in the issues that are considered paramount to a modern democracy, including the role of an independent media which can promote government accountability as well as the role of other independent bodies whose role it is to scrutinise and oversee the integrity of the Executive's activities.

Article IX states:

a. Steps which may be taken to encourage public sector accountability include:

The establishment of scrutiny bodies and mechanisms to oversee Government enhances public confidence in the integrity and acceptability of government's activities. Independent bodies such as Public Accounts Committees, Ombudsmen, Human Rights Commissions, Auditors-General, Anticorruption commissions, Information Commissioners and similar oversight institutions can play a key role in enhancing public awareness of good governance and rule of law issues. Governments are encouraged to establish or enhance appropriate oversight bodies in accordance with national circumstances. Government's transparency and accountability is promoted by an independent and vibrant media which is responsible, objective and impartial and which is protected by law in its freedom to report and comment upon public affairs.

The bodies referred to in article IX are essential in maintaining public confidence and awareness of the rule of law. They are also the front line in fighting against corruption, one of the priorities of Commonwealth countries seeking to develop economically. It is a well-proven fact that economic development requires a strong, effective, and transparent legal system. Foreign investment is not forthcoming without such the structures in place. The Principles urge the promotion of 'zero-tolerance' for corruption as being vital to good governance.

37 Report of the Southern African Chief Justices Forum on the fact-finding mission to the Republic of Seychelles, June 2018, available at <https://sacjforum.org> accessed 5 September 2018. 


\section{THE COMMONWEALTH PRINCIPLES (LATIMER HOUSE) ON THE RELATIONSHIP BETWEEN THE THREE BRANCHES OF GOVERNMENT}

In 2018, an ad hoc working group convened by the Commonwealth Journalists Association and including representatives of the CLA, CLEA and CPA adopted the 'Commonwealth Principles on Freedom of Expression and the Role of the Media in Good Governance' in what was a conscious imitation of the development of the Commonwealth (Latimer House) Principles. ${ }^{38}$ The promoters of these principles hope that they too will be embodied in some form by Heads of Government as part of the Commonwealth's fundamental values.

\section{CONCLUSION AND OVERVIEW}

The Commonwealth (Latimer House) Principles call for judiciaries and parliaments to 'fulfill their respective but critical roles' for otherwise this can severely impact on the good administration of justice. The Edinburgh Plan of Action noted that 'each new generation of government officers, parliamentarians, lawyers, judicial officers and members of civil society has to be alert to the imperatives of, and balance between, the independence and accountability of the judiciary, parliament and the executive.... ${ }^{39}$ Most problems which arise in the Commonwealth derive from a continued lack of understanding of each institution's role in the governance process. The Edinburgh Plan of Action also called for more regular awareness training, on appointment or election, of parliamentarians, judicial officers and public servants on basic constitutional principles and the primary roles of each pillar of democracy in the constitutional process.

In 2013, the Commonwealth Secretariat commissioned the CLA, CLEA, CMJA and CPA to develop a 'Latimer House Toolkit' to enhance the dialogue between the three pillars of democracy whilst not compromising their independence. Published in 2015, the four associations are still waiting in 2018 to assist the Commonwealth Secretariat to roll out of this toolkit in order to promote better respect between the three organs of the state in order to ensure that 'each Commonwealth country's Parliaments, Executives and Judiciaries are the guarantors in their respective spheres of the rule of law, the promotion and protection of fundamental human rights and the entrenchment of good governance

\footnotetext{
38 'The development of these principles has been inspired by the example of the Latimer House Principles': Commonwealth Principles on Freedom of Expression and the Role of the Media in Good Governance, Introduction p 3. The Principles <https://commonwealth. sas.ac.uk/sites/default/files/files/Publications/Commonwealth\%20principles $\% 20$ on $\% 20$ freedom $\% 20$ of $\% 20$ expression $\% 20$ and $\% 20$ the $\% 20$ role $\% 20$ of $\% 20$ the $\% 20$ media $\% 20 \mathrm{in} \% 20$ good\%20governance.pdf> accessed 5 September 2018.

39 Note (4) of the Edinburgh Plan of Action for the Development, Promotion and Implementation of the Commonwealth (Latimer House) Principles (2008), booklet p 40.
} 
based on the highest standards of honesty, probity and accountability'. In this, the Associations derive comfort from paragraph 13 of the CHOGM communiqué of April 2018:

Heads reaffirmed their commitment to the Commonwealth (Latimer House) Principles on the Accountability and the Relationship between the Three Branches of Government (2003) as an integral part of the Commonwealth's fundamental political values. Heads requested the Commonwealth Secretariat work in partnership with other Commonwealth organisations in promoting dialogue between the three branches of government, including through the full application of the Latimer House Toolkit, which provides a practical guide to enhancing the separation of powers. ${ }^{40}$

Thus the Latimer House process, twenty years on, is in Bourne's words, 'a spectacular example of the impact of Commonwealth associations on intergovernmental policy'. ${ }^{41}$ The Principles thus must be seen as a commitment to the core Commonwealth values and as a benchmark by which the performance of all Commonwealth countries should be judged.

40 The Toolkit, a comprehensive set of guidance in a number of volumes, with illustrative case-law from the Law Reports of the Commonwealth, Lexis-Nexis, 1985 to date, was published by the Commonwealth Secretariat in $2015<\mathrm{http}$ ://thecommonwealth.org/keyreform-area/57> accessed 20 November 2018.

${ }^{41}$ Bourne (n 12). 